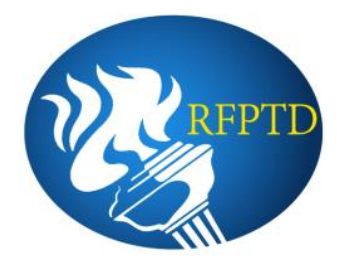

\section{OS PRINCÍPIOS DA IRRETROATIVIDADE E DA ANTERIORIDADE DA LEI TRIBUTÁRIA E A SÚMULA 584 DO STF* \\ THE PRINCIPLES OF NON-RETROACTIVITY AND ANTERIORITY OF TAX STATUTE OF LAW AND THE BRAZILIAN SUPREME COURT PRECEDENT 584}

Resumo: O presente artigo pretende analisar a interação dos princípios da irretroatividade e da anterioridade da lei tributária com a Súmula 584 do STF. Primeiramente, descrevemos as decisões que originaram a mencionada súmula, destacando os assuntos discutidos na época. Em segundo lugar, ressaltamos o sentido dos princípios da irretroatividade e da anterioridade da lei tributária, bem como seus impactos na validade das normas. Depois, analisamos como o Supremo Tribunal Federal vem se posicionando sobre as majorações de imposto de renda levadas a efeito durante o curso do período de apuração desde a promulgação da Constituição Federal de 1988. Ao final, criticamos a referida súmula e defendemos a sua revogação.

Palavras-chave: Imposto de renda; Majoração; Irretroatividade; Anterioridade.

Abstract: The present article aims to analyze the interaction of principles of non-retroactivity and anteriority of tax statute of law with the Brazilian Supreme Court precedent 584. First, we describe the decisions that leaded to mentioned court precedent, emphasizing the matters discussed at that time. Second, we highlight the meaning of the principles of non-retroactivity and anteriority of tax statute of law, as well as its impacts on the validity of statute of laws. Then, we analyze how Brazilian Supreme Court is ruling about income tax increases put into effect during the assessment period since the promulgation of the Brazilian Constitution of 1988. Finally, we criticize referred court precedent and advocate for its revocation.

Keywords: Income tax; Increase; Non-retroactivity; Anteriority.

\title{
INTRODUÇÃO
}

A Constituição Federal de 1988 (CF/88), em seu artigo 150, inciso III, alínea “a”, consagra expressamente, e pela primeira vez, o princípio da irretroatividade da lei tributária, vedando que os entes federados cobrem tributos em relação a fatos geradores ocorridos antes do início da vigência da lei que os houver instituído ou aumentado. ${ }^{1}$ Em complemento, a alínea "b" do aludido

\footnotetext{
${ }^{1}$ Nas Constituições Federais de 1934 (art. 113, §3), 1946 (art. 141, §3º), 1967 (art. 150, §3º) e na Emenda Constitucional (EC) $\mathrm{n}^{\circ} 01 / 69\left(\operatorname{art} .153, \S 3^{\circ}\right.$ ), estabelecia-se o princípio da irretroatividade de forma geral mediante disposição de que "A 
dispositivo proclama ser vedada também a cobrança de tributos no mesmo exercício financeiro em que haja sido publicada a lei que os instituiu ou aumentou. ${ }^{2}$

Tratam-se de duas garantias fundamentais do cidadão-contribuinte que zelam pela segurança jurídica e pela não surpresa, assim como privilegiam o planejamento e o conhecimento antecipado da carga tributária ${ }^{3}$, constituindo parâmetros a serem observador pelo legislador quando da instituição ou majoração de tributos.

Embora o art. 150, III da CF/88, em suas alíneas "a" e "b", tenha alcance amplo, abrangendo todos os tributos, salvo exceções constitucionalmente previstas, as disposições contidas no Código Tributário Nacional (CTN) - Lei n ${ }^{\circ}$ 5.172/66 - revelam-se dissonantes da disciplina trazida pela Carta Magna atual.

Por ser anterior ao texto constitucional em vigor e por não ter sofrido nenhuma reforma significativa nesse ínterim, o CTN mostra-se defasado no tocante aos contornos dados aos princípios da irretroatividade e da anterioridade. Os arts. $9^{\circ}$, II e 104 do CTN limitam a anterioridade aos impostos sobre o patrimônio e a renda, seguindo o que dispunha à época o art. $2^{\circ}$, II da EC $n^{\circ} 18 / 65$, ao passo que o art. 105 do CTN enuncia que a legislação tributária aplica-se imediatamente aos fatos geradores futuros e aos pendentes, assim entendidos aqueles cuja ocorrência tenha tido início mas não esteja completa, dando ensejo a posicionamentos no sentido de ser possível a lei tributária atingir fatos pretéritos atrelados a tributos cujo fato gerador seja periódico, a pretexto de que eles seriam meros componentes de um fato em formação, ainda não aperfeiçoado.

Com efeito, segundo essa corrente, bastaria que a lei fosse editada antes da implementação do último dos fatos isolados que integram o fato gerador do tributo para que fosse respeitado o princípio da irretroatividade da lei tributária.

Tal entendimento acabou sendo encampado pelo Supremo Tribunal Federal (STF), que, em matéria de imposto sobre a renda e proventos de qualquer natureza (IR), sedimentou

lei não prejudicará o direito adquirido, o ato jurídico perfeito e a coisa julgada", preceito esse que foi igualmente reproduzido pelo texto constitucional vigente (art. 5, XXXVI da CF/88). Já a Constituição imperial de 1824 (art. 179 , inciso III) e a Constituição Republicana de 1891, (art. 11, §3 ${ }^{\circ}$ ) vedavam a prescrição de leis com efeitos retroativos. No caso, a única Constituição que se omitiu a esse respeito foi a Carta totalitária de 1937, porém, em 1942, adveio o Decretolei no 4.657/42, instituindo a atual Lei de Introdução às normas do Direito Brasileiro (LINDB) que, em seu art. $6^{\circ}$, supriu tal lacuna no nosso ordenamento jurídico. Entendendo que a CF/88 não traz uma regra geral de irretroatividade, vide: PAULSEN, Leandro. Direito Tributário: Constituição e Código Tributário à luz da doutrina e da jurisprudência. 16. ed. Porto Alegre: Livraria do Advogado Editora; ESMAFE, 2014, p. 207-208.

${ }^{2} \mathrm{O}$ princípio da anterioridade tributária sucedeu o princípio da anualidade, mais amplo e previsto inicialmente na Constituição de 1946, que prescrevia que "nenhum tributo será exigido ou aumentado sem que a lei o estabeleça; nenhum será cobrado em cada exercício sem prévia autorização orçamentária" (art. 141, §34, CF/46). O princípio da anualidade foi revogado pela $\mathrm{EC} \mathrm{n}^{\circ} 18 / 65$ e retornou ao texto constitucional por meio do art. $150, \S 29$ da CF/67, porém, por curto espaço de tempo, sendo revogado pela $E C n^{\circ} 01 / 69$. No caso, tanto a $E C n^{\circ} 18 / 65$ como a $\mathrm{EC} \mathrm{n}^{\circ}$ 01/69 previam apenas o princípio da anterioridade, sendo que aquele dispositivo restringia o princípio da anterioridade para os impostos sobre patrimônio e renda, ao passo que este ampliava-o para todos os tributos.

${ }^{3}$ BALEEIRO, Aliomar. Direito tributário brasileiro. Atualizada por Misabel Abreu Machado Derzi. 12. ed. Rio de Janeiro: Forense, 2013, p. 97. 
jurisprudência no sentido de que a lei tributária que majorasse o citado imposto já seria aplicável sobre o respectivo fato gerador concreto a se consumar em 31 de dezembro desse mesmo ano, vindo, em seguida, a editar a Súmula $\mathrm{n}^{\circ} 584 / \mathrm{STF}$, de seguinte teor: "Ao imposto de renda calculado sobre os rendimentos do ano-base, aplica-se a lei vigente no exercício financeiro em que deve ser apresentada a declaração."

Nesse sentido, o presente artigo pretende analisar o enunciado da Súmula no $584 / \mathrm{STF}$ à luz dos princípios da irretroatividade e da anterioridade. Inicialmente, examinaremos os acórdãos do STF que deram origem ao referido verbete sumular, a fim de extrairmos os fundamentos de tais julgados. Em seguida, nos debruçaremos sobre o conteúdo carregado pelos princípios da irretroatividade e da anterioridade, destacando o seu impacto no âmbito de validade de outras normas, o que as torna inaptas a produzirem efeitos e a regularem os fatos ocorridos no exercício em que publicada a respectiva lei, na hipótese de inobservância de tais comandos. Após, observaremos que a jurisprudência do STF, mesmo após o advento da Constituição Federal de 1988, mostra-se claudicante quanto à aplicabilidade do enunciado da Súmula nº 584/STF para chancelar majorações de IR levadas a efeito durante o curso do período de apuração. Ao final, buscaremos demonstrar a incompatibilidade da súmula em comento com o sistema constitucional tributário vigente e a consequente necessidade de sua revogação pela Suprema Corte.

\section{A ORIGEM DA SÚMULA Nº 584/STF}

A interpretação consubstanciada na Súmula nº 584/STF começa a ser construída a partir do julgamento do Recurso em Mandado de Segurança (RMS) nº 18.112/GB, ocasião na qual a extinta Terceira Turma do STF entendeu não haver retroatividade na Lei $n^{\circ} 4.494$, de 25/11/1964, que, em seus artigos 31 e 32, sujeitava os rendimentos provenientes de aluguéis auferidos no ano anterior (no caso, o ano de 1964) a um recolhimento compulsório sob a forma de subscrição de letras imobiliárias do Banco Nacional de Habitação (BNH), cujo pagamento deveria ocorrer até o dia 31 de março de cada ano (no caso, o ano de 1965). Naquela assentada, o colegiado acolheu por unanimidade os argumentos do BNH para estabelecer uma distinção entre ano-base (ano de ocorrência do fato e que serve como base para a cobrança) e exercício financeiro (ano da exigência ou do pagamento), concluindo que não haveria retroatividade na edição de uma lei durante o ano-base, desde que a cobrança e o pagamento fossem efetuados no exercício financeiro subsequente. É ver a ementa do julgado: 

LEI TRIBUTARIA. DISTINÇÃO ENTRE ANO BASE E EXERCÍCIO FINANCEIRO.
RECURSO EM MANDADO DE SEGURANÇA DESPROVIDO. ${ }^{4}$

A propósito, colhe-se a seguinte passagem do voto condutor do acórdão:

Confunde o recorrente, assim, "exercício financeiro" com "ano base", esquecendo que exercício financeiro foi o do ano de 1965, quando a Lei passou a vigir [sic] e o ano base foi todo o ano anterior, o de 1964.

O locado presta obrigação relativa ao exercício de 1965 e os alugueres por ele percebidos em 1964 servem exclusivamente como BASE DE CÁLCULO. Assim, se o percentual incidisse sobre os alugueres de 1964, como alega o recorrente, o ano base seria o de 1963 e, assim, sucessivamente.

Ainda, para efeito de raciocínio, se o locador se desfizesse de seus imóveis em 1965 e, pois, nenhuma renda deles viesse a auferir, nenhuma subscrição lhe seria exigida, posto que a obrigação lhe seria exigida, posto que a obrigação se refere a esse mesmo exercício. É a mesma sistemática que rege o imposto de renda, sempre entendendo-se que as novas alíquotas desse tributo devem ser cobradas no exercício seguinte à sua a decretação, mas com base nos rendimentos do ano anterior, sem levar em conta, para esse efeito (base), a data da Lei.

Em seguida, no julgamento do Recurso Extraordinário (RE) no $65.112 / \mathrm{GB}^{5}$, foi a vez de a Primeira Turma do STF se filiar a esse entendimento, chancelando a incidência do empréstimo compulsório previsto nos arts. 31 e 32 da Lei ${ }^{\circ}$ 4.494/64 sobre os aluguéis vencidos antes da sua vigência, ao argumento de que o aludido diploma legal apenas utilizava os aluguéis percebidos no ano de 1964 como base de cálculo para a exação devida no ano de 1965, de sorte que não haveria retroatividade na lei porquanto a cobrança estava ocorrendo com base nos "aluguéis auferidos no ano anterior".

A esse respeito, destacamos excerto do voto do Ministro Djaci Falcão, in verbis:

\begin{abstract}
Ambas as regras [arts. 31 e 32 da Lei $n^{\circ}$ 4.494/64] deixam claro a incidência atual, isto é, a partir da vigência da lei, da contribuição compulsória por ela instituída. Apenas adota como base de cálculo para fixação do quantum da contribuição o rendimento proveniente de aluguéis "auferidos no ano anterior". Não há cogitar de retroatividade da lei, para efeitos da cobrança do empréstimo compulsório. Os aluguéis percebidos em 1964, vale insistir, entram apenas como base de cálculo.
\end{abstract}

Apesar de os acórdãos supracitados não figurarem entre aqueles que deram origem à Súmula $n^{\circ} 584 / \mathrm{STF}$, uma vez que não tratavam de discussão envolvendo o IR, estamos diante dos primeiros arestos em que a Suprema Corte estabeleceu a distinção entre ano-base e exercício financeiro para assentar que não há retroatividade em eventual mudança legislativa produzida antes do encerramento do ano-base, quando a exação seja cobrada no exercício financeiro subsequente. ${ }^{6}$

\footnotetext{
${ }^{4}$ STF, RMS 18.112/GB, Relator(a): Min. Amaral Santos, Terceira Turma, julgado em 22/11/1968, DJ 06/02/1969.

${ }^{5}$ STF, RE 65.612/GB, Relator(a): Min. Barros Monteiro, Primeira Turma, julgado em 25/03/1969, DJ 29/12/1969.

${ }^{6}$ O STF já havia apreciado a controvérsia em torno da Lei no 4.494/64 sob o ângulo do princípio da anualidade, porém, como existia à época jurisprudência firmada pelo caráter não tributário do empréstimo compulsório (Súmula nº 418/STF),
} 
Ato contínuo, ao se debruçar sobre o Recurso Extraordinário no $74.594 / \mathrm{GB}$, a Segunda Turma do STF valeu-se justamente dessa distinção entre ano-base e exercício financeiro para consignar que a majoração decorrente da revogação do art. $2^{\circ}$ da Lei $n^{\circ} 4.480 / 64$ pelo art. 15 do Decreto-lei $n^{\circ} 62 / 66$, acabando com o privilégio fiscal dos magistrados, que até então recolhiam o imposto de renda com base em 2 (dois) meses de seus vencimentos, era aplicável para efeito de declaração do IR no exercício de 1967, relativo ao ano-base de 1966. Eis a ementa do julgado:

IMPOSTO DE RENDA. ANO-BASE E EXERCÍCIO FINANCEIRO. INOCORRENCIA DE APLICAÇÃO RETROATIVA DA LEI. RECURSO EXTRAORDINÁRIO NÃO CONHECIDO. ${ }^{7}$

Na mesma linha, quando do julgamento dos Recursos Extraordinários $n^{\circ} 80.250 / \mathrm{GB}^{8}$ e $n^{\circ}$ $80.620 / \mathrm{RJ}^{9}$, a Segunda Turma do STF reiterou o entendimento de que, embora percebidos no anobase, os rendimentos estão sujeitos à tributação segundo a lei vigente no exercício financeiro que a ela se referir.

Todavia, importante frisar que nas decisões colegiadas ora mencionadas a questão controvertida foi decidida exclusivamente à luz do princípio da irretroatividade, não havendo, em nenhum momento, qualquer debate acerca do princípio da anterioridade, o qual, vale frisar, já existia desde o ano de 1966 por obra do CTN (art. $104^{10}$ ) e era aplicável ao imposto sobre a renda. ${ }^{11}$ Não obstante, diversos julgados posteriores à aprovação da Súmula nº 584/STF rejeitam o argumento dos contribuintes de ofensa à anterioridade tributária com fundamento no referido verbete, criando falsos obstáculos para sua superação.

\section{OS PRINCÍPIOS DA IRRETROATIVIDADE E DA ANTERIORIDADE EM MATÉRIA TRIBUTÁRIA}

\subsection{O PRINCÍPIO DA IRRETROATIVIDADE DA LEI TRIBUTÁRIA GRAVOSA}

\footnotetext{
decidiu-se que a exigência da exação não estava sujeita à prévia autorização orçamentária (cf. STF, RMS 18.073/RJ, Relator(a): Min. Aliomar Baleeiro, Segunda Turma, julgado em 03/04/1968, DJ 07/06/1968).

${ }^{7}$ STF, RE 74.594/GB, Relator(a): Min. Xavier de Albuquerque, Segunda Turma, julgado em 26/02/1973, DJ 23/03/1973.

${ }^{8}$ STF, RE 80.250/GB, Relator(a): Min. Xavier de Albuquerque, Segunda Turma, julgado em 10/12/1974, DJ 18/02/1975.

${ }^{9}$ STF, RE 80.620/RJ, Relator(a): Min. Xavier de Albuquerque, Segunda Turma, julgado em 06/05/1975, DJ 02/06/1975.

${ }^{10}$ Art. 104. Entram em vigor no primeiro dia do exercício seguinte àquele em que ocorra a sua publicação os

dispositivos de lei, referentes a impostos sobre o patrimônio ou a renda:

I - que instituem ou majoram tais impostos;

II - que definem novas hipóteses de incidência;

III - que extinguem ou reduzem isenções, salvo se a lei dispuser de maneira mais favorável ao contribuinte, e observado o disposto no artigo 178.

${ }^{11}$ QUEIROZ, Luís Cesar Souza de. Imposto sobre a renda, os princípios da irretroatividade e da anterioridade e a Súmula 584 do STF. In: GOMES, Marcus Lívio Gomes; VELLOSO, Andrei Pitten. (org.). Sistema Constitucional Tributário: dos fundamentos teóricos aos hard cases tributários: estudos em homenagem ao ministro Luiz Fux. Porto Alegre: Livraria do Advogado, 2014, p. 83.
} 
A proibição de retroatividade é corolário da segurança jurídica, da proteção da confiança na lei e da não surpresa ${ }^{12}$, estando prevista em alguns dispositivos ${ }^{13}$ do atual texto constitucional, aqui nos interessando, particularmente, o art. 150, inciso III, alínea "a" da CF/88, que consagra o princípio da irretroatividade da lei tributária gravosa.

Contudo, para compreendermos o seu sentido é fundamental, antes, nos debruçarmos sobre o fenômeno da retroatividade.

Como bem destacado por Luís Cesar Souza de Queiroz, uma norma jurídica é retroativa sempre que se reporta a fato que ocorreu ou pode ter ocorrido no passado. O caráter retroativo da norma refere-se sempre ao seu antecedente, que descreve fato ou fatos que ocorreram ou podem ter ocorrido no passado. Nunca ao consequente normativo, que sempre está projetado para o futuro. ${ }^{14}$

Nesse sentido, o ponto de referência para que a norma seja qualificada como retroativa é o momento em que a norma começa a ter vigência, isto é, está apta a produzir efeitos jurídicos. Logo, se o antecedente se refere a uma situação de fato que pode ter ocorrido antes de a norma jurídica iniciar sua vigência, tal norma é retroativa.

Falar em "efeito retroativo" da norma significa a possibilidade de a norma tomar um fato ocorrido (ou que possa ter ocorrido) no passado e atribuir como resultado a produção de certo efeito jurídico projetado necessariamente para o futuro. Por isso, revela-se mais adequado o uso da expressão norma com caráter retroativo ou, simplesmente, norma retroativa.

Feito esse esclarecimento, verifica-se que o tratamento específico conferido pelo art. 150, III, “a” da Carta Republicana de 1988 deixa clara a impossibilidade de haver a instituição ou majoração de tributo com caráter retroativo. Nos termos do art. 106 do $\mathrm{CTN}^{15}$, a retroatividade só

\footnotetext{
${ }^{12}$ Luciano Amaro considera que o princípio da irretroatividade é desdobramento do princípio da legalidade (AMARO, Luciano da Silva. O imposto de renda e os princípios da irretroatividade e da anterioridade. Revista de Direito Tributário, n. $25 / 26,1983$, p. 141$)$.

${ }^{13}$ É o caso, por exemplo, do art. $5^{\circ}$, XXXVI da CF/88, que veda a retroatividade da lei em prejuízo do direito adquirido, do ato jurídico perfeito e da coisa julgada; assim como do art. $5^{\circ}$, XXXIX e XL da CF/88, que trata da irretroatividade da lei penal.

${ }^{14}$ Vale lembrar que a norma jurídica apresenta uma estrutura lógica dual, composta por um antecedente e um consequente. O antecedente descreve uma situação de fato e funciona como condicionante, como implicante do efeito jurídico prescrito no consequente. (QUEIROZ, Luís Cesar Souza de. Imposto sobre a renda, os princípios da irretroatividade e da anterioridade e a Súmula 584 do STF. In: GOMES, Marcus Lívio Gomes; VELLOSO, Andrei Pitten. (org.). Sistema Constitucional Tributário: dos fundamentos teóricos aos hard cases tributários: estudos em homenagem ao ministro Luiz Fux. Porto Alegre: Livraria do Advogado, 2014, p. 84)

${ }^{15}$ Art. 106. A lei aplica-se a ato ou fato pretérito:

I - em qualquer caso, quando seja expressamente interpretativa, excluída a aplicação de penalidade à infração dos dispositivos interpretados;

II - tratando-se de ato não definitivamente julgado:

a) quando deixe de defini-lo como infração;

b) quando deixe de tratá-lo como contrário a qualquer exigência de ação ou omissão, desde que não tenha sido fraudulento e não tenha implicado em falta de pagamento de tributo;

c) quando lhe comine penalidade menos severa que a prevista na lei vigente ao tempo da sua prática.
} 
tem assento para leis interpretativas e leis punitivas mais benéficas ao contribuinte. Afora tais hipóteses, a norma tributária (criadora ou aumentadora da respectiva carga) não pode incidir sobre fatos $^{16}$ ocorridos antes de tal norma entrar em vigor, pois o princípio da irretroatividade obsta a atribuição de efeitos jurídicos novos a atos ou fatos já ocorridos ${ }^{17}$.

Tal proibição, aliás, evidencia uma relação de complementariedade entre o princípio da irretroatividade e o princípio da legalidade. Enquanto este exige lei em sentido estrito para o surgimento da obrigação tributária, aquele determina que a referida lei seja anterior ao próprio fato tributado. $^{18}$

Assim, não basta tomar como referência apenas o aspecto temporal da norma tributária para se aferir se houve ou não ofensa ao princípio da irretroatividade. Para verificação da observância do referido princípio, há que se considerar o início da vigência da lei (e não a sua publicação ${ }^{19}$ ), bem como a data da ocorrência do fato gerador (o qual será considerado em seus diversos aspectos, em especial, o material e o quantitativo), sendo certo que o princípio da irretroatividade veda a incidência da lei instituidora ou majoradora do tributo sobre fatos que ocorreram antes de sua vigência (ainda que após a publicação da lei), mesmo que a cobrança do tributo só venha a ocorrer posteriormente. ${ }^{20}$

Em se tratando de tributos com fato gerador periódico (caso do imposto de renda), a irretroatividade exige que a lei seja prévia ao início do período ${ }^{21}$, havendo, a propósito, disposições expressas nesse sentido nas legislações portuguesa ${ }^{22}$ e italiana $^{23}$. A lei deve preceder todo o conjunto de fatos jurídicos isolados (e relevantes) para a composição do fato gerador do tributo, porque este último se realiza ao longo do período-base, constituindo uma unidade indissolúvel e incindível na

\footnotetext{
${ }^{16}$ Comungando do mesmo entendimento de Luciano Amaro, entendemos que o texto do art. 150, III, "a" da CF/88 não foi feliz ao falar em "fatos geradores", afinal, o fato anterior à vigência da lei que institui o tributo não é gerador. Só há que se falar em fato gerador anterior à lei nos casos de majoração de tributo, e não de instituição (AMARO, Luciano. Direito tributário brasileiro. 17. ed. São Paulo: Saraiva, 2011, p. 141).

${ }^{17}$ AMARO, Luciano da Silva. O imposto de renda e os princípios da irretroatividade e da anterioridade. Revista de Direito Tributário, n. 25/26, 1983, p. 146.

${ }^{18}$ SCHOUERI, Luís Eduardo. Direito tributário. 3. ed. São Paulo: Saraiva, 2013, p. 322. No mesmo sentido, Carlos Mário da Silva Velloso afirma que o princípio da legalidade tributária perderia sentido se fosse possível fazer retroagir a lei para apanhar fatos a ela anteriores (VELLOSO, Carlos Mário da Silva. Irretroatividade da lei tributária Irretroatividade e anterioridade - Imposto de renda e empréstimo compulsório. Revista de Direito Tributário, n. 45, v. 12, 1988, p. 84).

${ }^{19}$ A publicação da lei tem relevância para a satisfação dos princípios da legalidade (eis que é o marco final do processo legislativo) e da anterioridade (posto que representa o termo inicial para verificação de sua observância). Contudo, para fins de aplicação do princípio da irretroatividade da lei tributária, a publicação é irrelevante, porquanto a $\mathrm{CF} / 88$ toma como referência o início da vigência, ou seja, o momento em que a regra jurídica está apta a incidir, a produzir efeitos.

${ }^{20}$ VELLOSO, Andrei Pitten. Constituição tributária interpretada. 2. ed., rev., atual. e ampl. Porto Alegre: Livraria do Advogado Editora, 2012, p. 251.

${ }^{21}$ PAULSEN, Leandro. Direito Tributário: Constituição e Código Tributário à luz da doutrina e da jurisprudência. 16. ed. Porto Alegre: Livraria do Advogado Editora; ESMAFE, 2014, p. 209.

22 Art. 103, item 3 da Constituição da República Portuguesa de 1976 e art. 12 do Decreto-lei no $398 / 99$ (Lei Geral Tributária).

${ }^{23}$ Art. 3 da Legge 27 luglio 2000, n. 212 (Statuto dei diritti del contribuente).
} 
qual são computados fatos positivos e negativos relacionados à aquisição de disponibilidade econômica ou jurídica de renda ou proventos de qualquer natureza. ${ }^{24}$

A circunstância de o fato gerador implementar-se ao longo de um período de tempo não tem o condão de protelar a subsunção do fato gerador periódico à lei que vier a ser editada até o último dia do período de formação desse fato. Suas consequências são apenas (i) que o fato gerador periódico não se confunde com os fatos isolados que o compõem e (ii) que o lançamento e a cobrança do tributo ficam protraídos para um momento posterior ao lapso temporal de formação do fato gerador. $^{25}$

\subsection{O PRINCÍPIO DA ANTERIORIDADE DE EXERCÍCIO}

Enquanto que a irretroatividade se volta para o passado, protegendo os fatos anteriores à vigência da lei, a anterioridade se dirige para o futuro, impedindo que a lei nova, instituidora ou majoradora do tributo, atinja fatos ocorridos no mesmo exercício financeiro em que publicada. ${ }^{26-27}$ Nas palavras de Andrei Pitten Velloso, "o princípio da anterioridade abrange o da irretroatividade e garante mais, assegurando aos contribuintes um período mínimo para ter conhecimento da alteração tributária e para adequar-se a ela" 28 .

Assim como a irretroatividade, a anterioridade tem por embasamento a segurança jurídica, a proteção da confiança na lei, a exclusão da surpresa fiscal e a garantia ao prévio planejamento das finanças do contribuinte, constituindo cláusula pétrea instituída em favor dos contribuintes (art. $60, \S 4^{\circ}$ da $\mathrm{CF} / 88$ ), consoante já firmado pelo $\mathrm{STF}^{29}$. O verbo "cobrar" utilizado pelo legislador constituinte no art. 150, III, "b" da CF/88 abrange a instituição, a incidência e a cobrança de tributos no mesmo exercício financeiro em que haja sido publicada a lei que os instituiu ou aumentou, sob pena de tornar sem efeito a aludida limitação constitucional ao poder de tributar,

\footnotetext{
${ }^{24}$ Entendendo pela necessidade de cisão do fato gerador do imposto de renda para que os fatos isolados sejam regidos, conforme o caso, pela lei sob cujo pálio foram praticados, vide: VELLOSO, Carlos Mário da Silva. Irretroatividade da lei tributária - Irretroatividade e anterioridade - Imposto de renda e empréstimo compulsório. Revista de Direito Tributário, n. 45, v. 12, 1988, p. 88; XAVIER, Alberto. Direito tributário e empresarial: pareceres. Rio de Janeiro: Forense, 1982, p. 71-75.

${ }^{25}$ AMARO, Luciano da Silva. O imposto de renda e os princípios da irretroatividade e da anterioridade. Revista de Direito Tributário, n. 25/26, 1983, p. 145.

${ }^{26}$ MENDES, Frana Elizabeth. Imposto sobre a renda - súmula 584 atualizada com a EC 42 e EC 45. São Paulo: Quartier Latin, 2006, p. 124.

${ }^{27} \mathrm{Na}$ lição de Luciano Amaro, “o princípio da anterioridade qualifica a irretroatividade da lei tributária: se a lei tributária cria ou majora tributo não sujeito àquele princípio, a irretroatividade é simples; se cria ou majora tributo por ele acobertado, a irretroatividade é qualificada, pois não basta a antecedência da lei em relação ao fato jurígeno, exigindo-se essa antecedência em relação ao ano (ou exercício) da realização do fato" (cf. AMARO, Luciano da Silva. O imposto de renda e os princípios da irretroatividade e da anterioridade. Revista de Direito Tributário, n. 25/26, 1983, p. 151-152).

${ }^{28}$ VELLOSO, Andrei Pitten. Constituição tributária interpretada. 2. ed., rev., atual. e ampl. Porto Alegre: Livraria do Advogado Editora, 2012, p. 266.

${ }^{29}$ STF, ADI 939/DF, Relator(a): Min. Sydney Sanches, Tribunal Pleno, julgado em 15/12/1993, DJ 18/03/1994.
} 
convertendo-a num mero comando de inércia temporária da Fazenda Pública no tocante à tomada das providências administrativas para a cobrança do tributo, porém, sem qualquer reflexo no campo das obrigações tributárias. ${ }^{30-31}$

Diversamente da irretroatividade, que se preocupa com a data de início da vigência da lei instituidora ou majorado do tributo, a anterioridade adota como marco temporal a data de publicação da lei, por nós entendida como o ato por meio do qual o texto legal torna-se passível de conhecimento por toda população, o que, por conseguinte, demanda a circulação do Diário Oficial. Contudo, o STF já flexibilizou essa prova de circulação do Diário Oficial para chancelar a constitucionalidade de leis editadas nos últimos dias de um ano para vigorar no primeiro dia do exercício subsequente, havendo, a propósito, dois casos emblemáticos.

No primeiro, o Estado de Minas Gerais editou uma lei no dia 31 de dezembro à noite, tendo os exemplares do Diário Oficial sido entregues aos assinantes apenas no dia 2 de janeiro. Ainda assim, ao julgar o Agravo Regimental em Agravo de Instrumento n ${ }^{\circ}$ 244.414/ $\mathrm{MG}^{32}$, a Primeira Turma do STF, apontando a existência de um único exemplar na portaria da Imprensa Oficial, entendeu não haver violação aos princípios da irretroatividade e da anterioridade, contentando-se com a mera formalização no Diário Oficial, dispensando o requisito de que a nova lei se tornasse pública.

Poucos anos depois, em uma majoração de tributo promovida pela União Federal através de lei editada no dia 31 de dezembro - na época, um sábado, portanto, dia sem expediente nas repartições públicas - a Primeira Turma do STF, ao apreciar o Recurso Extraordinário $\mathrm{n}^{\circ}$ 232.084/RS ${ }^{33}$, aceitou a prova de que pelos menos uma pessoa havia adquirido o exemplar do Diário Oficial para considerar que houve a notícia do aumento da carga tributária, sendo, pois, respeitado o princípio da anterioridade. ${ }^{34}$

Tais aumentos de tributo ocorridos nos últimos dias do ano com a finalidade de vigorar já no primeiro dia do exercício seguinte, ao contarem com o beneplácito do STF, não só evidenciaram a insuficiência da anterioridade de exercício enquanto garantia individual do cidadão-contribuinte,

\footnotetext{
${ }^{30}$ VELLOSO, Andrei Pitten. Constituição tributária interpretada. 2. ed., rev., atual. e ampl. Porto Alegre: Livraria do Advogado Editora, 2012, p. 266-267.

${ }^{31}$ A tese que beneficia a Fazenda Pública interpreta o termo "cobrar" do art. 150, III "b" da CF/88 no sentido de que a publicação da lei permite sua vigência imediata e consequente desencadeamento de efeitos, daí nascendo a relação jurídica tributária, sendo necessário aguardar a mudança de exercício apenas para fins de cobrança do tributo. Entretanto, o mero retardamento da cobrança do tributo até o exercício seguinte não se coaduna com o princípio da anterioridade das leis tributárias, porquanto não evita a surpresa tributária e acaba por reduzir o período de espera a prazo de pagamento. De acordo com Misabel Abreu Machado Derzi, o efeito da anterioridade é obstar a eficácia das normas que criam ou aumento tributos, impedindo sua aplicabilidade, executoriedade e exigibilidade até o exercício subsequente àquele no qual tenham entrado em vigor. Na mesma linha, vide: BALEEIRO, Aliomar. Direito tributário brasileiro. Atualizada por Misabel Abreu Machado Derzi. 12. ed. Rio de Janeiro: Forense, 2013, p. 98-100.

${ }^{32}$ STF, AI 244.414 AgR/MG, Relator(a): Min. Moreira Alves, Primeira Turma, julgado em 19/10/1999, DJ 12/11/1999.

${ }^{33}$ STF, RE 232.084/SP, Relator(a): Min. Ilmar Galvão, Primeira Turma, julgado em 04/04/2000, DJ 16/06/2000.

${ }^{34}$ SCHOUERI, Luís Eduardo. Direito tributário. 3. ed. São Paulo: Saraiva, 2013, p. 312.
} 
mas também contribuíram decisivamente para a futura promulgação da $\mathrm{EC} \mathrm{n}^{\circ} 42 / 03$, que incluiu a alínea "c" no art. 150, inciso III da CF/88, conferindo maior efetividade ao princípio da segurança jurídica ao trazer a anterioridade nonagesimal como lapso temporal mínimo a ser respeitado pelas Fazendas entre a publicação da lei que instituiu ou majorou o tributo e a sua cobrança.

Lamentavelmente, o constituinte derivado excepcionou o imposto sobre a renda do rol de tributos submetidos ao princípio da anterioridade nonagesimal (art. 150, $\S 1^{\circ}$ da $\mathrm{CF} / 88$ ), perdendo uma ótima oportunidade de minorar o debate em torno dos sentidos dos princípios da irretroatividade e da anterioridade de exercício.

\subsection{CONSEQUÊNCIA DA INOBSERVÂNCIA DOS PRINCÍPIOS DA IRRETROATIVIDADE E DA ANTERIORIDADE: INVALIDADE DA NORMA}

Questão importante, e sobre a qual tem divergido a doutrina, reside em saber se os princípios da irretroatividade e da anterioridade informam a validade ou a vigência da norma jurídica, com vistas a perquirir qual a consequência da sua eventual inobservância. Para tanto, é fundamental que, antes, esclareçamos cada um desses conceitos.

A validade é a qualidade da norma jurídica produzida regularmente, em consonância com os requisitos estabelecidos pela correspondente norma de produção normativa ${ }^{35}$, ao passo que a vigência é a qualidade da norma jurídica (portanto, válida) que está apta a produzir efeitos jurídicos mediante a incidência sobre fatos.

Uma norma válida significa uma norma que pertence a um sistema de direito positivo por ter sido regularmente produzida, isto é, de acordo com os ditames da correspondente norma de produção normativa. A seu turno, uma norma jurídica vigente é aquela norma que, além de já ter sido produzida em consonância com o prescrito pela respectiva norma de produção normativa - o que a faz ingressar no sistema do Direito positivo, tornando-a jurídica (e válida) - encontra-se passível de incidir sobre fatos, atribuindo-lhes efeitos jurídicos.

\footnotetext{
${ }^{35}$ As normas jurídicas podem ser classificadas quanto ao critério do que é objeto imediato de regulação como sendo de produção normativa ou de conduta. Como ensina Luís Cesar Souza de Queiroz, a norma de produção normativa é aquela cujo antecedente descreve uma específica situação de fato (de ocorrência possível), que se caracteriza por apresentar os requisitos necessários para que outra norma passe a pertencer (a ter validade) ou deixe de pertencer (revogação) ao sistema jurídico, e cujo consequente apresenta uma estrutura relacional, composta por variáveis, que simboliza a norma jurídica a ser criada, modificada ou revogada. Por sua vez, a norma de conduta é aquela cujo antecedente descreve uma situação de fato qualquer, de possível ocorrência, e cujo consequente apresenta a regulação de uma conduta intersubjetiva, por meio de uma permissão, obrigação ou proibição. (QUEIROZ, Luís Cesar Souza de. Sujeição passiva tributária. 3. ed. Rio de Janeiro: LMJ Mundo Jurídico, 2016, p. 53)
} 
Disso resulta que uma norma válida pode não ser vigente, porém, uma norma vigente nunca poderá ser inválida. Afinal, se uma norma é inválida, ela não é jurídica e, não sendo jurídica, não há que se falar em vigência, pois a vigência é uma qualidade das normas que são jurídicas. ${ }^{36}$

Fixadas tais premissas, infere-se que os princípios da irretroatividade e da anterioridade estão contidos em norma constitucional de produção normativa relativa à instituição ou alteração (implicadora de aumento do tributo) de norma impositiva tributária (norma de conduta), apresentando-se como requisitos constitucionais de validade desta última. Ou seja, se não forem atendidas tais diretrizes, não haverá a produção de uma norma válida e, portanto, dotada de juridicidade.

Neste contexto, por força dos princípios da irretroatividade e da anterioridade, e lembrando que este abrange aquele, a lei que dispuser sobre a instituição ou a majoração de tributo, se publicada em um exercício financeiro, só poderá implicar a incidência da nova norma sobre fato que ocorra no exercício subsequente. Até que se dê essa mudança de exercício, tem-se uma norma inválida e que, portanto, não pertence ao sistema jurídico, sendo incapaz de regular os fatos ocorridos no próprio exercício em que publicada a respectiva lei.

\section{A JURISPRUDÊNCIA DO STF APÓS A CONSTITUIÇÃO FEDERAL DE 1988}

Após o advento da Constituição Federal de 1988, a doutrina amplamente majoritária, que antes mesmo já se posicionava contra o enunciado da Súmula $n^{\circ} 584 / \mathrm{STF}$, contando com certa simpatia do extinto Tribunal Federal de Recursos (TFR) ${ }^{37}$, passou a entender que o referido verbete havia sido suplantado pelo novo texto constitucional ${ }^{38}$, posição essa que veio a ser encampada $a$ posteriori pelo Superior Tribunal de Justiça (STJ) ${ }^{39}$.

\footnotetext{
${ }^{36}$ QUEIROZ, Luís Cesar Souza de. Sujeição passiva tributária. 3. ed. Rio de Janeiro: LMJ Mundo Jurídico, 2016, p. 123128.

${ }^{37} \mathrm{O}$ TFR, por meio de sua $5^{\text {a }}$ Turma, já havia decidido pela inaplicabilidade da Súmula no ${ }^{\circ}$ 584/STF à luz da disciplina trazida pelo Código Tributário Nacional, por considerar que este identificou o fato gerador do imposto de renda como a aquisição da disponibilidade econômica ou jurídica da renda e dos proventos, no seu fluxo continuado, até o encerramento do seu ciclo, afastando a orientação anterior no sentido de que a renda auferida no ano-base seria apenas "padrão de estimativa" da renda ganha no exercício financeiro, ou simples valor de referência (TFR, AC 82. 686/PR, Rel. Min. Sebastião Reis, Quinta Turma, julgado em 26/03/1984, DJ 03/05/1984). Posteriormente, contudo, a $6^{a}$ Turma do TFR entendeu pela aplicabilidade da Súmula ${ }^{\circ}$ 584/STF com temperamentos, seccionado o fato gerador do imposto de renda para considerar, para o cálculo do imposto, os fatos seriam regidos pela lei vigente à época (TFR, AMS 107.919/MG, Rel. p/ acórdão Min. Eduardo Ribeiro, Sexta Turma, julgado em 17/12/1986, DJ 19/03/1987)

${ }^{38}$ Por todos: COÊLHO, Sacha Calmon Navarro. Comentários à Constituição de 1988: sistema tributário. 8. ed. Rio de Janeiro: Forense, 1999, p. 235-236; BALEEIRO, Aliomar. Direito tributário brasileiro. Atualizada por Misabel Abreu Machado Derzi. 12. ed. Rio de Janeiro: Forense, 2013, p. 416-417.

${ }^{39}$ STJ, REsp 46.430/RS, Rel. Ministro Milton Luiz Pereira, Primeira Turma, julgado em 21/08/1995, DJ 25/09/1995; STJ, REsp 41.208/SP, Rel. Ministro Adhemar Maciel, Segunda Turma, julgado em 04/12/1997, DJ 16/02/1998; STJ, REsp 133.844/PR, Rel. Ministro Humberto Gomes de Barros, Primeira Turma, julgado em 15/09/1998, DJ 03/11/1998; STJ, REsp 419.814/RS, Rel. Ministro Luiz Fux, Primeira Turma, julgado em 24/09/2002, DJ 28/10/2002; STJ, REsp 
Não obstante tida por superada pela doutrina, a jurisprudência do Pretório Excelso mostrou-se claudicante quanto à revogação da Súmula no 584/STF.

Ao julgar a Ação Direta de Inconstitucionalidade $n^{\circ}$ 513/STF ${ }^{40}$, o Plenário do STF considerou que o coeficiente de aumento do imposto de renda previsto na Lei ${ }^{\circ}$ 8.134, de 27/12/1990, não poderia alcançar os fatos ocorridos no ano-base de 1990, por força dos princípios da irretroatividade e da anterioridade.

Já quando do julgamento do Recurso Extraordinário no 197.790/MG, o Pleno da Suprema Corte afastou a alegação de ofensa à irretroatividade (e à anterioridade nonagesimal) pela Lei $n^{\circ}$ 7.856/89, fruto da conversão da Medida Provisória (MP) no 86, de 25/09/1989, a qual majorou a alíquota da contribuição social sobre o lucro a ser apurado no balanço do próprio exercício de 1989.

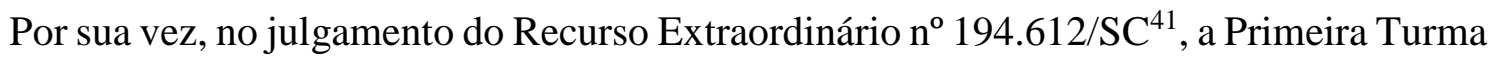
do STF considerou que o aumento de alíquota do imposto sobre a renda previsto pela Lei $\mathrm{n}^{\mathrm{o}} 7.988$, de 28/12/1989, já seria aplicável sobre o fato gerador a se consumar no dia 31/12/1989, invocando justamente a o entendimento cristalizado na Súmula no 584/STF.

Ato contínuo, por ocasião do julgamento do Recurso Extraordinário n ${ }^{\circ} 199.352 / \mathrm{PR}^{42}$, foi a vez de a Segunda Turma do STF admitir que o adicional ao imposto de renda instituído pelo Decreto-lei no 2.462, de 31/08/1988, já incidiria sobre o fato gerador a ser apurado em 31/12/1988, entendimento esse que foi reiterado pela Suprema Corte em outras assentadas ${ }^{43}$.

Em seguida, ao julgar o Recurso Extraordinário $\mathrm{n}^{\mathrm{o}} 232.084 / \mathrm{SP}^{44}$, a Primeira Turma do STF chancelou que o aumento de carga tributária provocado pela MP n 812, de 31/12/1994 convertida na Lei $n^{\circ} 8.981 / 95$ e que reduziu a $30 \%$ (trinta por cento) a parcela dos prejuízos fiscais de exercícios anteriores suscetível de ser deduzida no lucro real, para apuração do imposto de renda - já incidisse sobre o resultado do exercício financeiro de 1994, encerrado no mesmo dia.

Ulteriormente, ao analisar o Recurso Extraordinário no $587.008 / \mathrm{SP}^{45}$, o Plenário do STF consignou que a EC n ${ }^{\circ}$ 10, publicada em 07/03/1996, ao dar nova redação aos arts. 71 e 72 do ADCT,

\footnotetext{
222.338/RS, Rel. Ministro Castro Meira, Segunda Turma, julgado em 01/09/2005, DJ 03/10/2005. Embora nos arestos retromencionados a majoração do tributo tenha ocorrido após o encerramento do exercício, porém, antes da sua cobrança, é de se notar que o STJ já rechaçou também o aumento de tributo previsto em lei editada dentro do ano-base, tendo, na oportunidade, a Ministra Eliana Calmon consignado que "a Súmula 584STF está superada nos moldes colocados no seu verbete, entendendo-se que na atual redação da CF/88 aplica-se ao Imposto de Renda a lei vigente no ano antecedente, de modo a já estar ela com plena eficácia no início do ano-base.” (STJ, EDcl no REsp 377.099/RS, Rel. Ministra Eliana Calmon, Segunda Turma, julgado em 02/03/2004, DJ 17/05/2004).

${ }^{40}$ STF, ADI 513/DF, Relator(a): Min. Célio Borja, Tribunal Pleno, julgado em 14/06/1991, DJ 30/10/1992.

${ }^{41}$ STF, RE 194.612/SC, Relator(a): Min. Sydney Sanches, Primeira Turma, julgado em 24/03/1998, DJ 08/05/1998.

${ }^{42}$ STF, RE 199.352/PR, Relator(a): Min. Marco Aurélio, Relator(a) p/ Acórdão: Min. Nelson Jobim, Segunda Turma, julgado em 06/02/2001, DJ 09/08/2002.

${ }_{43}^{43}$ STF, RE 177.091 AgR/PR, Relator(a): Min. Carlos Britto, Primeira Turma, julgado em 22/03/2005, DJ 10/03/2006; STF, RE 229.147 AgR/MG, Relator(a): Min. Carlos Velloso, Segunda Turma, julgado em 13/05/2003, DJ 06/06/2003.

${ }^{44}$ STF, RE 232.084/SP, Relator(a): Min. Ilmar Galvão, Primeira Turma, julgado em 04/04/2000, DJ 16/06/2000.

${ }^{45}$ STF, RE 587.008/SP, Relator(a): Min. Dias Toffoli, Tribunal Pleno, julgado em 02/02/2011, DJe 05/05/2011.
} 
restaurando a exigência da contribuição social sobre o lucro à alíquota de $30 \%$ (trinta por cento) para determinados contribuintes e pretendendo fazê-la retroagir a janeiro de 1996, violou os princípios da irretroatividade e da anterioridade nonagesimal (art. 195, $\S 6^{\circ} \mathrm{da} \mathrm{CF} / 88$ ).

Ao se debruçar sobre o Agravo Regimental no Recurso Extraordinário no 553.508/PR ${ }^{46}$, a Segunda Turma do STF considerou constitucional a MP nº 492/94, ressaltando que a jurisprudência da Corte é no sentido de que o fato gerador do imposto de renda se materializa no último dia do anobase (31 de dezembro), de modo a lei que entra em vigor antes do último dia do período de apuração poderá ser aplicada a todo o ano-base, sem ofensa ao princípio da anterioridade tributária.

No julgamento do Recurso Extraordinário n ${ }^{\circ} 208.526 / \mathrm{RS}^{47}$, o Pleno da Suprema Corte declarou inconstitucional o art. 30 da Lei $\mathrm{n}^{\mathrm{o}}$ 7.799, de 10/07/1989, que propugnou a indexação de balanço relativo àquele ano, por violar o princípio da irretroatividade, porquanto a mudança no padrão de correção interfere na apuração do lucro real, base de cálculo do imposto de renda da pessoa jurídica, e, portanto, não poderia o legislador estabelecer uma sistemática que entra em vigor em julho e captura período anterior daquele mesmo ano. O posicionamento firmado naquela assentada foi posteriormente reiterado pelo Tribunal Pleno quando do julgamento do Recurso Extraordinário $\mathrm{n}^{\circ}$ $188.083 / \mathrm{PR}^{48}$.

Ao apreciar o Recurso Extraordinário no $183.130 / \mathrm{PR}^{49}$, o Plenário do STF reviu sua jurisprudência acerca da constitucionalidade da Lei $n^{\circ} 7.988 / 89$, que majorou a alíquota do imposto de renda incidente sobre o lucro proveniente de operações incentivadas ocorridas no passado, ainda que no mesmo ano-base, posicionando-se, dessa vez, pela inconstitucionalidade do referido diploma legal. Contudo, na ocasião, o Tribunal Pleno considerou que a utilização do imposto de renda com conotação extrafiscal afasta a incidência da Súmula n ${ }^{\circ}$ 584/STF, daí derivando a inconstitucionalidade da aplicação retroativa do art. $1^{\circ}$, I da Lei $n^{\circ} 7.988 / 89$, pois o fato gerador ocorre a cada operação de exportação incentivada pela redução da alíquota do imposto. Mais tarde, tal entendimento foi reafirmado sob o regime de repercussão geral, por ocasião do julgamento do Recurso Extraordinário $\mathrm{n}^{\mathrm{o}} 592.396 / \mathrm{SP}^{50}$.

\footnotetext{
${ }^{46}$ STF, RE 553.508 AgR/PR Relator(a): Min. Ellen Gracie, Segunda Turma, julgado em 03/05/2011, DJe 16/05/2011.

${ }^{47}$ STF, RE 208.526/RS, Relator(a): Min. Marco Aurélio, Tribunal Pleno, julgado em 20/11/2013, DJe 29/10/2014. A Medida Provisória ${ }^{\circ} 32$, de 15/01/1989, transformada na Lei $\mathrm{n}^{\circ} 7.730$, de 31/01/1989, afastou a indexação do balanço relativo àquele ano. Ocorre que, posteriormente, por força da Lei $\mathrm{n}^{\circ} 7.799 / 89$, optou-se por retomar a indexação, adotandose como padrão a Obrigação do Tesouro Nacional (OTN). Segundo a prescrição legal, o novo indexador seria aplicado a partir do balanço levantado em 31/12/1988. A lei continha, ainda, uma previsão de que os saldos das contas seriam convertidos em Bônus do Tesouro Nacional (BTN), tomando-se como referência o valor da OTN. Em que pese a Lei ${ }^{\circ}$ 7.799/89 tenha entrado em vigor no mês de julho de 1989, constara do referido diploma determinação para que o período a ser indexado retroagisse a $1^{\circ}$ de fevereiro daquele mesmo exercício.

${ }^{48}$ STF, RE 188.083/PR, Relator(a): Min. Marco Aurélio, Tribunal Pleno, julgado em 05/08/2015, DJe 19/10/2015.

${ }^{49}$ STF, RE 183.130/PR, Relator(a): Min. Carlos Velloso, Relator(a) p/ Acórdão: Min. Teori Zavascki, Tribunal Pleno, julgado em 25/09/2014, DJe 14/11/2014.

${ }_{50}$ STF, RE 592.396/SP, Relator(a): Min. Edson Fachin, Tribunal Pleno, julgado em 03/12/2015, DJe 22/03/2016.
} 
Frente a tal cenário, percebe-se que a jurisprudência do STF tem oscilado quanto à aplicabilidade da Súmula n ${ }^{\circ}$ 584/STF nos dias atuais.

Em relação à retroatividade própria, que ocorre quando a lei alcança fatos ocorridos ou relações jurídicas formadas antes da sua vigência, o Pretório Excelso tem afastado a aplicação do referido verbete sumular quando a nova lei gravosa advém após o encerramento do período de apuração do imposto de renda.

Contudo, nas hipóteses de retroatividade imprópria, verificável quando a lei nova não atua sobre o passado nem sobre o futuro, mas sobre eventos em formação, atingindo um presente ainda não concluído quando do seu advento ${ }^{51}$, nota-se que a Corte Suprema ainda não pacificou de vez a sua jurisprudência, havendo 5 (cinco) acórdãos de Plenário pela inaplicabilidade da Súmula $\mathrm{n}^{\circ}$ 584/STF (ADI 513/DF, RE 587.008/SP, RE 183.130/PR, RE 188.083/PR e RE 592.396/SP), sendo que os dois últimos dão ênfase ao caráter extrafiscal da tributação na espécie para afastar a aludida súmula; e 1 (um) acórdão do Pleno (RE 197.790/MG) e acórdãos dos órgãos fracionários do STF pela sua aplicabilidade.

\title{
4 O ANACRONISMO DA SÚMULA No 584/STF E A NECESSIDADE DE SUA REVOGAÇÃO
}

A manutenção da Súmula no $584 / \mathrm{STF}$, mesmo após a promulgação da Carta Cidadã de 1988, tem causado perplexidades na doutrina, que há muito rechaça seu enunciado por considerá-lo ofensivo aos princípios da irretroatividade e da anterioridade tributárias, com especial destaque para Luciano Amaro, que, em maio de 1983, fez aprovar tese nas XI Jornadas Latino-Americanas de Direito Tributário de seguinte redação:

\begin{abstract}
A aquisição da disponibilidade de renda resulta de fatos (voluntários ou não) que se produzem ao longo do período, e que são fatos jurídicos relevantes para efeito da lei tributária. Por isso e em face dos princípios da anterioridade, da irretroatividade e da segurança do direito (a não surpresa, a evitação do arbítrio), bem como as demais implicações do Estado de Direito, é vedada a alteração da lei, para criar ou aumentar o imposto, após iniciado o período. ${ }^{52}$
\end{abstract}

Deveras, valendo-se da distinção entre retroatividade própria e imprópria, a jurisprudência do STF passou a interpretar com temperamentos a Súmula no 584/STF, posto que seu enunciado abre espaço para que o legislador majore o imposto de renda - e a contribuição social sobre

\footnotetext{
${ }^{51}$ MENDES, Frana Elizabeth. Imposto sobre a renda - súmula 584 atualizada com a EC 42 e EC 45. São Paulo: Quartier Latin, 2006, p. 120; VELLOSO, Andrei Pitten. Constituição tributária interpretada. 2. ed., rev., atual. e ampl. Porto Alegre: Livraria do Advogado Editora, 2012, p. 254.

52 AMARO, Luciano da Silva. O imposto de renda e os princípios da irretroatividade e da anterioridade. Revista de Direito Tributário, n. 25/26, 1983, p. 146.
} 
lucro (tributo cujo fato gerador também é periódico) - durante o ano-base ou até mesmo em momento posterior ao seu encerramento, desde que dentro do prazo para apresentação da declaração (no exercício subsequente), o que precariza os princípios da irretroatividade e da anterioridade

Nos casos de retroatividade própria, em que a lei incide sobre fatos perfeitos e acabados antes do início da sua vigência, a Suprema Corte tem corretamente vedado que alterações legislativas onerosas advindas em momento posterior ao encerramento do período-base retroajam para alcançar os fatos ocorridos durante esse lapso temporal, por considerar que o fato gerador do imposto sobre a renda já se consumou no dia 31 de dezembro passado, devendo, pois, ser regido pela lei vigente à época.

Por outro lado, no que se refere às hipóteses de retroatividade imprópria, em que a mudança legislativa gravosa produzida no curso do ano-base com a pretensão de atingir todos os fatos ocorridos no período de apuração do imposto de renda, a orientação do STF ainda não é uniforme, havendo julgados em sentidos antagônicos.

Os partidários da Súmula no 584/STF costumam invocar o art. 105 do CTN $^{53-54}$ para endossar o entendimento de que, em matéria de imposto de renda, as leis podem ser editadas até o final do período para aplicar-se à renda que estava se formando a partir do primeiro dia do período, eis que o fato gerador do imposto estaria "pendente", é dizer, sua ocorrência já teria tido início, porém, não se teria completado. Ocorre que tal entendimento, a nosso ver, confunde fato gerador pendente com fato gerador periódico, além do que carece de amparo constitucional, sobretudo diante dos princípios da irretroatividade e da anterioridade.

O fato gerador de período é um acontecimento que se desenrola ao longo de um lapso temporal em que são levados em consideração determinados fatos isolados para a concretização do fato gerador do tributo. Já o fato gerador pendente, a que faz alusão o art. 105 do CTN, é aquele fato sujeito a condição suspensiva que ainda não se implementou, ou seja, é fato futuro, despido de juridicidade para fins tributários. Tanto que o referido dispositivo faz remissão ao art. 116, que, por sua vez, é complementado pelo art. 117 do CTN, que esclarece quando se reputam perfeitos e acabados os atos ou negócios jurídicos condicionais para efeito de configuração do fato gerador do tributo. 55

Adicionalmente, caso se entendesse pela aplicação do art. 105 do CTN aos fatos geradores periódicos, o referido dispositivo legal se mostraria, então, incompatível com os princípios da

\footnotetext{
${ }^{53}$ Art. 105. A legislação tributária aplica-se imediatamente aos fatos geradores futuros e aos pendentes, assim entendidos aqueles cuja ocorrência tenha tido início mas não esteja completa nos termos do artigo 116.

${ }^{54}$ Hugo de Brito Machado entende que o art. 105 do CTN não foi recepcionado pela Constituição de 1988 (MACHADO, Hugo de Brito. Curso de direito tributário. 33. ed. São Paulo: Malheiros, 2012, p. 100).

55 PAULSEN, Leandro. Direito Tributário: Constituição e Código Tributário à luz da doutrina e da jurisprudência. 16. ed. Porto Alegre: Livraria do Advogado Editora; ESMAFE, 2014, p. 961.
} 
irretroatividade e da anterioridade tributárias, o que nos conduziria à conclusão de que o mesmo não foi recepcionado pela nova ordem constitucional.

Conforme já exposto, a irretroatividade veda que a lei tributária gravosa atinja fatos pretéritos, o que, no caso dos tributos de fato gerador periódico, demanda que a lei seja anterior ao seu período de formação, isto é, que anteceda todo o conjunto de fatos isolados que compõem o fato gerador do tributo. A seu turno, a anterioridade exige lei prévia ao exercício em que ocorram os fatos que darão nascimento à obrigação tributária, e não apenas ao exercício de cobrança. ${ }^{56}$

Com efeito, se o fato tido por "pendente" for passível de tributação e sua ocorrência já tiver se iniciado, a lei tributária posterior que pretender atingir tal fato de modo mais gravoso será retroativa, o que esbarra no art. 150, III, "a" da CF/88. E mais: por força do princípio da anterioridade, consagrado no art. 150, III, “b” da CF/88, essa nova lei onerosa não poderá alcançar qualquer fato futuro, mas tão somente aqueles ocorridos em exercícios futuros. ${ }^{57}$

O princípio da anterioridade qualifica o da irretroatividade, impedindo a aplicação da norma nova no exercício de sua publicação, ainda que seu advento se dê antes do encerramento do ano-base. Tais princípios, como expusemos anteriormente, informam a validade da norma, e não a sua vigência, de sorte que a nova norma só ingressará no sistema jurídico após o cumprimento dos requisitos neles contidos, os quais, ao serem conjugados, levam à necessidade de espera da mudança de exercício, sem o que a norma não será válida e, por conseguinte, não estará apta a incidir sobre os fatos para atribuir-lhes consequências jurídico-tributárias. Dessa feita, como a lei nova só poderá incidir sobre fatos futuros e ocorridos a partir do exercício financeiro seguinte, sob pena de incorrer em retroação e em violação à anterioridade, quedará incólume o período relevante para a apuração da renda (ano-base anterior), o que demonstra a impertinência de se cogitar na admissibilidade da chamada retroatividade imprópria. ${ }^{58}$

Igualmente entendendo ser descabida a retroatividade imprópria no direito tributário brasileiro, em virtude do malferimento aos princípios da irretroatividade e da anterioridade, a Ministra Ellen Gracie, em voto proferido no julgamento do Recurso Extraordinário no 587.008/SP, pontuou com acerto que é o aspecto material (e não o aspecto temporal) da norma de incidência tributária que deve ser considerado para fins de resguardo da irretroatividade e da anterioridade de exercício. Isso porque o aspecto temporal da norma tributária impositiva, quando não corresponda ao próprio momento da ocorrência material do fato gerador, constitui ficção jurídica voltada a facilitar a

\footnotetext{
${ }^{56}$ AMARO, Luciano. Direito tributário brasileiro. 17. ed. São Paulo: Saraiva, 2011, p. 143; 154.

${ }^{57}$ AMARO, Luciano. Direito tributário brasileiro. 17. ed. São Paulo: Saraiva, 2011, p. 225-226.

${ }^{58}$ BALEEIRO, Aliomar. Direito tributário brasileiro. Atualizada por Misabel Abreu Machado Derzi. 12. ed. Rio de Janeiro: Forense, 2013, p. 1022.
} 
aplicação da lei tributária, não servindo, contudo, de referência para a verificação da observância das garantias da irretroatividade e da anterioridade tributárias.

Nas palavras da eminente Ministra:

Havendo afirmação constitucional expressa da irretroatividade da lei ao fato gerador, bem como da anterioridade da lei tributária, e considerando-se que tais garantias constituem desdobramentos inequívocos do princípio da segurança jurídica, pode-se concluir que não tem lugar, no direito tributário brasileiro, a chamada retroatividade imprópria. [...] Ainda que se considere ocorrido o fato gerador da contribuição social sobre o lucro anual em 31 de dezembro de cada ano, é certo que o fato gerador se forma ao longo do período, desde $1^{\circ}$ de janeiro até 31 de dezembro. [...] Só se estará assegurando efetivamente o conhecimento antecipado da lei tributária ao contribuinte, preservando-o do imprevisto e do inesperado e facultando-lhe tempo hábil para a organização das suas atividades em face da carga tributária real, se a garantia constitucional for aplicada com atenção à própria ocorrência material do fato gerador. ${ }^{59}$

Com efeito, por força do princípio da irretroatividade, a norma impositiva (criada ou modificada) não pode se projetar, isto é, incidir sobre fatos já ocorridos no tempo e no espaço, eis que estes acontecimentos isolados integram o aspecto material da regra-matriz de incidência tributária. Da mesma forma, em função do princípio da anterioridade, estende-se essa vedação à exigência do tributo sobre todos os fatos ocorridos no exercício financeiro em que se deu a publicação da respectiva lei instituidora ou majoradora, a qual só prevalecerá após a ocorrência de evento futuro e certo, qual seja: o encerramento do exercício financeiro em que foi publicada. ${ }^{60}$ Por exclusão, antes da chegada desse termo, a norma emanada do texto legal encontra-se despida de contornos jurídicos por ser ainda inválida.

Assim, a nosso ver, revela-se equivocada a assertiva de que a irretroatividade e a anterioridade afetam a vigência da norma, eis que isso implicaria pressupor que a norma foi produzida regularmente (e, portanto, ingressou no sistema jurídico), porém, ainda não está apta a gerar efeitos jurídicos. Com a devida vênia, advogar tal entendimento é não enxergar que os referidos princípios integram norma constitucional de produção normativa, trazendo condicionantes para que outra norma passe a pertencer (a ter validade) ao sistema jurídico. No caso do princípio da anterioridade, então, significaria transformá-lo em mero mecanismo de postergação do vencimento do prazo de pagamento do tributo, posição com a qual não concordamos e que mereceu a devida repulsa por parte da

\footnotetext{
${ }^{59}$ STF, RE 587.008/SP, Relator(a): Min. Dias Toffoli, Tribunal Pleno, julgado em 02/02/2011, DJe 05/05/2011.

${ }^{60}$ QUEIROZ, Luís Cesar Souza de. Sujeição passiva tributária. 3. ed. Rio de Janeiro: LMJ Mundo Jurídico, 2016, p. 151152.
} 
doutrina $^{61}$ e da jurisprudência do $\mathrm{STF}^{62}$, que entendem que a inobservância da anterioridade caracteriza hipótese de inconstitucionalidade, é dizer, de norma (não jurídica) carente de fundamento de validade em norma constitucional de produção normativa.

Isto posto, ao se ignorar que os princípios da irretroatividade e da anterioridade informam a obtenção de validade jurídica da norma tributária, afetando o momento do seu ingresso no sistema jurídico, fica evidente o equívoco do entendimento cristalizado na Súmula no 584/STF, donde exsurge a necessidade de sua revogação em prestígio aos princípios ora mencionados, e não o seu afastamento em casos pontuais como vem fazendo a Suprema Corte, perdendo a oportunidade de colocar uma pá de cal na discussão e homenagear a certeza e a segurança na tributação.

Embora o legislador federal ${ }^{63}$ venha se portando de maneira mais deferente aos princípios da irretroatividade e da anterioridade, evitando produzir leis que aumentem o IR nos últimos dias do exercício financeiro corrente, é fundamental que o STF revogue o entendimento consagrado na Súmula $n^{\circ} 584 / \mathrm{STF}$, de modo a homenagear a segurança jurídica e a não surpresa fiscal, bem como impedir que os demais Tribunais do país continuem a aplicar o enunciado da aludida súmula, sob a justificativa do dever de observância ao sistema de precedentes judiciais ${ }^{64}$.

\section{CONCLUSÃO}

Como visto, a Súmula $n^{\circ} 584 / \mathrm{STF}$ tomou por base acórdãos relativos (i) à subscrição compulsória de letras imobiliárias do Banco Nacional de Habitação, em valor calculado com base na renda auferida da cobrança de aluguéis e (ii) ao imposto de renda devido por pessoas físicas (magistrados), não havendo, à época, qualquer debate acerca do argumento de ofensa ao princípio da anterioridade, embora tal garantia já estivesse prevista e fosse aplicável ao imposto de renda.

A nosso ver, a Súmula $n^{\circ} 584 / \mathrm{STF}$ fere, a um só tempo, os princípios da irretroatividade e da anterioridade, os quais informam a validade da norma tributária e, uma vez conjugados, vedam

\footnotetext{
${ }^{61}$ Por todos, vide: QUEIROZ, Luís Cesar Souza de. Imposto sobre a renda, os princípios da irretroatividade e da anterioridade e a Súmula 584 do STF. In: GOMES, Marcus Lívio Gomes; VELLOSO, Andrei Pitten. (org.). Sistema Constitucional Tributário: dos fundamentos teóricos aos hard cases tributários: estudos em homenagem ao ministro Luiz Fux. Porto Alegre: Livraria do Advogado, 2014, p. 90-92.

${ }^{62}$ STF, ADI 513/DF, Relator(a): Min. Célio Borja, Tribunal Pleno, julgado em 14/06/1991, DJ 30/10/1992; STF, ADI 939/DF, Relator(a): Min. Sydney Sanches, Tribunal Pleno, julgado em 15/12/1993, DJ 18/03/1994.

${ }^{63}$ A título exemplificativo, ver: AMARO, Luciano. Direito tributário brasileiro. 17. ed. São Paulo: Saraiva, 2011, nota 50, p. 156. Na mesma linha, e mais recentemente, podemos mencionar o aumento de IR promovido pela Medida Provisória $n^{\circ} 692 / 15$, que introduziu a progressividade na tributação sobre o ganho de capital percebido por pessoa física. ${ }^{64}$ Esta obrigatoriedade de respeito à jurisprudência dos Tribunais Superiores foi reforçada com a chegada do Novo Código de Processo Civil (Lei no 13.105/15), cujo art. 927, inciso IV, reza: “Art. 927. Os juízes e os tribunais observarão: [...] IV - os enunciados das súmulas do Supremo Tribunal Federal em matéria constitucional e do Superior Tribunal de Justiça em matéria infraconstitucional;".
} 
que a instituição ou o aumento do tributo alcance fatos pretéritos e fatos futuros ocorridos no mesmo exercício em que publicada a nova lei.

Em se tratando de tributos cujo fato gerador é periódico, como é o caso do imposto de renda, isso significa que não só é vedado o aumento da carga tributária após o encerramento do período de formação do fato jurídico tributário, mas também durante esse lapso temporal, haja vista que somente com a chegada do novo exercício financeiro é que a nova norma tributária gravosa obterá validade jurídica, estando apta a incidir sobres os fatos a serem tributados.

A circunstância de a regra-matriz de incidência do imposto de renda somente incidir no final do ano-base não torna irrelevante os fatos isolados ocorridos no seu ciclo de formação, uma vez que estes integram o seu aspecto material, sendo informadores da renda e, por conseguinte, juridicamente relevantes.

Por fim, nota-se que o STF tem interpretado restritivamente a Súmula $n^{\circ}$ 584/STF, afastando a sua aplicação quando a alteração legislativa acontece após o encerramento do período de apuração da renda. Entretanto, nas hipóteses em que a majoração do tributo é levada a cabo no curso do período de apuração, a jurisprudência da Suprema Corte ainda se mostra oscilante, malgrado hoje já existam importantes decisões do Tribunal Pleno rechaçando o entendimento cristalizado no citado verbete.

\section{REFERÊNCIAS}

AMARO, Luciano. Direito tributário brasileiro. 17. ed. São Paulo: Saraiva, 2011.

AMARO, Luciano da Silva. O imposto de renda e os princípios da irretroatividade e da anterioridade. Revista de Direito Tributário, n. 25/26, 1983.

BALEEIRO, Aliomar. Direito tributário brasileiro. Atualizada por Misabel Abreu Machado Derzi. 12. ed. Rio de Janeiro: Forense, 2013.

COÊLHO, Sacha Calmon Navarro. Comentários à Constituição de 1988: sistema tributário. 8. ed. Rio de Janeiro: Forense, 1999.

MACHADO, Hugo de Brito. Curso de direito tributário. 33. ed. São Paulo: Malheiros, 2012.

MENDES, Frana Elizabeth. Imposto sobre a renda - súmula 584 atualizada com a EC 42 e EC 45. São Paulo: Quartier Latin, 2006.

PAULSEN, Leandro. Direito Tributário: Constituição e Código Tributário à luz da doutrina e da jurisprudência. 16. ed. Porto Alegre: Livraria do Advogado Editora; ESMAFE, 2014. 
QUEIROZ, Luís Cesar Souza de. Imposto sobre a renda, os princípios da irretroatividade e da anterioridade e a Súmula 584 do STF. In: GOMES, Marcus Lívio Gomes; VELLOSO, Andrei Pitten. (org.). Sistema Constitucional Tributário: dos fundamentos teóricos aos hard cases tributários: estudos em homenagem ao ministro Luiz Fux. Porto Alegre: Livraria do Advogado, 2014.

QUEIROZ, Luís Cesar Souza de. Sujeição passiva tributária. 3. ed. Rio de Janeiro: LMJ Mundo Jurídico, 2016.

SCHOUERI, Luís Eduardo. Direito tributário. 3. ed. São Paulo: Saraiva, 2013.

VELLOSO, Andrei Pitten. Constituição tributária interpretada. 2. ed., rev., atual. e ampl. Porto Alegre: Livraria do Advogado Editora, 2012.

VELLOSO, Carlos Mário da Silva. Irretroatividade da lei tributária - Irretroatividade e anterioridade - Imposto de renda e empréstimo compulsório. Revista de Direito Tributário, n. 45, v. 12, 1988.

XAVIER, Alberto. Direito tributário e empresarial: pareceres. Rio de Janeiro: Forense, 1982. 